\title{
Spatial orientation by prairie rattlesnakes (Crotalus viridis) following the predatory strike
}

\author{
KARL KANDLER \\ Universität Tübingen, Tübingen, Federal Republic of Germany \\ and \\ DAVID CHISZAR \\ University of Colorado, Boulder, Colorado
}

\begin{abstract}
Mice (Mus musculus) were suspended for 10 sec into the home cages of prairie rattlesnakes (Crotalus viridis) without touching the walls or floors. All tongue flicks (TFs) emitted by the rattlesnakes were recorded for 20 min following removal of prey, and separate tallies were made of TFs emitted in the right and left sides of the cages. More TFs were emitted in the side in which prey had been suspended than in the opposite side, regardless of whether the mouse was struck during the 10 -sec presentation. It is concluded that rattlesnakes orient to the place briefly occupied by prey and that subsequent chemosensory searching is aimed according to this orientation. After a successful strike, this could facilitate subsequent location of the trail deposited by the envenomated prey (which is usually released following the strike). When there has been no opportunity for a strike, the direction of TFs toward the spot previously occupied by prey may facilitate relocation of the prey (i.e., stalking).
\end{abstract}

Rattlesnakes typically release adult rodents after the envenomating strike, allowing the dying prey to wander freely while venom takes effect (Estep, Poole, Radcliffe, O'Connell, \& Chiszar, 1981; Hays \& Galusha, 1984; Kardong, 1982; Reinert, Cundall, \& Busher, 1984). The snakes then use vomeronasal chemoreception to follow the trail left by the wounded rodent (Chiszar, Radcliffe, Scudder, \& Duvall, 1983; Dullemeijer, 1961; Halpern \& Kubie, 1980; see Burghardt, 1970, for a review of the earlier literature). Under natural conditions, there will always be two chemical trails available to the predator following the strike: the trail deposited by the rodent as it wandered into striking range and the one deposited after envenomation. Although there is evidence that rattlesnakes prefer to follow the second (i.e., the postenvenomation) trail, it is not clear that chemical cues alone account for this discrimination (Chiszar, Radcliffe, Scudder, \& Duvall, 1983; see also Duvall, Scudder, \& Chiszar, 1980). It is possible that the predators observe (visually, thermally, and/or chemically) the vanishing bearing of the prey as the prey wanders away after the strike. If the snake maintains this orientation as it begins searching for a chemical trail, then it is likely that the postenvenomation trail segment will be encountered first. The present ex-

This work was completed while K. Kandler was an exchange student at the University of Colorado. Reprint requests should be addressed to D. Chiszar, Department of Psychology, Campus Box 345, University of Colorado, Boulder, CO 80309. periment assessed the extent to which the poststrike spatial orientation of prairie rattlesnakes was biased toward an area formerly occupied by prey (even though no chemical cues were deposited on the substrate).

\section{METHOD}

Subjects were 6 adult prairie rattlesnakes (Crotalus viridis) captured in northeastern Colorado and maintained in the laboratory for at least 3 years prior to the present study. The snakes were housed individually in glass terraria $(62 \times 32 \times 32 \mathrm{~cm})$ containing paper floor coverings and stainless steel vessels filled with water. Temperature was $26 \pm 1^{\circ} \mathrm{C}$ during photophase (0700-1900) and $23 \pm 1^{\circ} \mathrm{C}$ at night. Snakes were fed 1 mouse (Mus musculus, 15-20 g) every other week. The present observations were taken between $1400-1700$, prior to a regularly scheduled feeding session.

A mouse was suspended into a snake's home cage and held (out of striking range, about $25-30 \mathrm{~cm}$ above the floor) either on the right or left side of the cage for $10 \mathrm{sec}$. Then the mouse was either removed (i.e., no strike condition) or lowered into striking range. Snakes always struck and released prey in the latter case (i.e., strike condition), and the mouse was removed immediately afterward. Prey were always introduced and removed through the same side of the cage. After mice were removed, all tongue flicks emitted by the snakes were recorded for the the next $20 \mathrm{~min}$, and tongue flicks emitted on the left and right sides of the cage were recorded separately. If rattlesnakes selectively orient toward the place last occupied by prey, then more tongue flicks should be emitted in the side of the cage through which the prey was introduced and removed, even though the mouse never touched the floor or walls of the cage during these tests (hence, there was no chemical trail).

All snakes were observed after a no-strike (NS) and a strike (S) presentation, and the order of these presentations was counterbalanced. Mice were presented equally often in the left and right sides of snake cages. In this discussion, the letter $M$ designates the side in which mice were presented; NM designates the opposite side. 
Table 1

Mean Number of Tongue Flicks Emitted by Rattlesnakes

\begin{tabular}{|c|c|c|c|c|c|}
\hline & \multicolumn{2}{|c|}{$\begin{array}{c}\text { No Strike } \\
\text { Presentation }\end{array}$} & \multicolumn{2}{|c|}{$\begin{array}{c}\text { Strike } \\
\text { Presentation } \\
\end{array}$} & \multirow{2}{*}{$\begin{array}{c}F \text { Ratio } \\
\text { for M vs. NM } \\
\text { Effect } \\
(d f=1,5)\end{array}$} \\
\hline & Side $\mathbf{M}$ & Side NM & Side $\mathbf{M}$ & Side NM & \\
\hline $\begin{array}{l}\text { Minutes 1-5 } \\
\text { Postpresentation }\end{array}$ & 96.5 & 18.2 & 95.8 & 63.8 & $23.22 *$ \\
\hline $\begin{array}{l}\text { Minutes 1-20 } \\
\text { Postpresentation }\end{array}$ & 223.9 & 51.5 & 480.2 & 330.9 & $8.57 *$ \\
\hline
\end{tabular}

$M=$ side in which mouse had been suspended; $N M=$ side in which no mouse had been suspended. ${ }^{*} p<.05$.

\section{RESULTS}

Table 1 shows the mean number of tongue flicks emitted in the two sides of the home cage following NS and $S$ presentations. Separate analyses of variance (ANOVAs) were executed on data gathered 1-5 $\mathrm{min}$ and on data gathered 1-20 min following prey removal. Both ANOVAs revealed that more tongue flicks were directed at Side $M$ than at Side NM.

More tongue flicks were emitted after S presentations than after NS presentations, but this difference was not significant during Minutes 1-5 $[F(1,5)=2.12, p>.05]$, although it was robust in the ANOVA applied to data from Minutes 1-20 $[F(1,5)=25.69, p<.05]$. The NS versus $S$ effect did not interact significantly with the $M$ versus NM factor in either ANOVA ( $p$ s $>.05$ ).

\section{DISCUSSION}

Mice were introduced and removed through the same side of the snakes' home cages, because controlled NS and S presentations would have been impossible otherwise. For example, snakes would probably have been able to strike mice in NS conditions if the prey were passed from one side of the cage through the other. Of course, these problems can easily be solved by using a larger test environment than is provided by a home cage. However, it was considered acceptable to confound entering and departing directions of the prey in this initial study, because our goal here was to determine whether any change in spatial orientation could be detected in rattlesnake chemosensory behavior following mouse presentations in which no chemical cues were deposited on the substrate.

Since the snakes concentrated their chemosensory searching in the side of the cage that had briefly contained a prey item, it is concluded that the predators do not exhibit a random search pattern following the departure of a mouse (see also Gillingham \& Clark, 1981). However, it is not possible to say that the snakes register the vanishing bearing of envenomated prey and use this information to guide subsequent chemosensory searching. To permit this conclusion, it will be necessary to introduce and remove prey through different compass directions and to show that the snakes orient according to the prey's vanishing path rather than to the entering path. Furthermore, it will be necessary to conduct such experiments with artificial mice (i.e., models) as well as real ones so that the effects of visual, thermal, and chemical cues on the orientation process can be separated (Graves \& Duvall, 1985; Scudder, in press).

Snakes exhibited more chemosensory investigation of Side $\mathbf{M}$ than of Side NM after both S and NS presentations. If snakes do, in fact, take the vanishing bearings of their departing prey, then it seems reasonable to hypothesize that such orientations may be used not only to lo- cate the proper trail segment following a successful strike, but also to guide stalking behavior when a rodent has passed by without entering striking range (Chiszar, Stimac, \& Boyer, 1983; Gillingham \& Clark, 1981).

\section{REFERENCES}

BURGHARDT, G. M. (1970). Chemical perception in reptiles. In F. W. Johnston, D. G. Moulton, \& A. Turk (Eds.), Communication by chemical signals (pp. 241-308). New York: Appleton-Century-Crofts.

Chiszar, D., Radcliffe, C. W., Scudder, K. M., \& Duvall, D. (1983). Strike-induced chemosensory searching by rattlesnakes: The role of envenomation-related chemical cues in the post-strike environment. In D. Muller-Schwarze \& R. Silverstein (Eds.), Chemical signals in vertebrates (Vol. 3, pp. 1-24). New York: Plenum Press.

Chiszar, D. Stimac, K., \& BoYer, T. (1983). Effect of mouse odors on visually-induced and strike-induced chemosensory searching in prairie rattlesnakes (Crotalus viridis). Chemical Senses, 7, 301-308.

DULlEMEIJER, P. (1961). Some remarks on the feeding behavior of rattlesnakes. Koninklijke Nederlandische Academie von Wetenschappen (Series C), 64, 383-396.

Duvall, D., Scudder, K. M., \& Chiszar, D. (1980). Rattlesnake predatory behaviour: Mediation of prey discrimination, and release of swallowing by odors associated with envenomated mice. Animal Behaviour, 28, 674-683.

Estep, K., Poole, T., Radcliffe, C. W., O'Connell, B., \& Chiszar, D. (1981). Distance traveled by mice (Mus musculus) after envenomation by a rattlesnake (Crotalus viridis). Bulletin of the Psychonomic Society, 18, 108-110.

Gillingham, J. C., \& ClaRK, D. L. (1981). An analysis of prey searching behavior in the western diamondback rattlesnake, Crotalus atrox. Behavioral \& Neural Biology, 32, 235-240.

Graves, B., \& Duvall, D. (1985). Avomic prairie rattlesnakes (Crotalus viridis) fail to attack rodent prey. Zeitschrift für Tierpsychologie, 67, 161-166.

Halpern, M., \& Kubie, J. L. (1980). Chemical access to the vomeronasal organs of garter snakes. Physiology \& Behavior, 24, 367-371.

HAYS, W. K., \& Galusha, F. G. (1984). Effects of rattlesnake (Crotalus viridis oroganus) envenomation upon mobility of male wild and laboratory mice (Mus musculus). Bulletin of the Maryland Herpetological Society, 20, 135-144.

KARDONG, K. V. (1982). Comparative study of changes in prey capture behavior of the cottonmouth (Agkistrodan piscivorus) and Egyptian cobra (Naje naje). Copeia, 337-343.

Reinert, H. K., Cundall, D., \& Busher, L. M. (1984). Foraging behavior of the timber rattlesnake, Crotalus horridus. Copeia, 976-981.

SCUDDER, K. M. (in press). Roles of chemical and other cues in the predatory sequence of rattlesnakes. In D. Muller-Schwarze, R. M. Silverstein, \& D. Duvall (Eds.), Chemical signals in vertebrates (Vol. 4). New York: Plenum Press.

(Manuscript received for publication October 30, 1985.) 